\title{
BioDiesel as Additive in High Pressure and Temperature Steam Recovery of Heavy Oil and Bitumen
}

\author{
T. Babadagli ${ }^{1 *}$ and B. Ozum² \\ 1 University of Alberta, Department of Civil and Environmental Engineering, School of Mining and Petroleum Engineering, \\ 3-1 12 Markin CNRL-NREF, Edmonton, AB, T6G 2W2 - Canada \\ 2 Apex Engineering Inc., Edmonton, Alberta-Canada \\ e-mail: tayfun@ualberta.ca - apexeng@telusplanet.net \\ * Corresponding author
}

\begin{abstract}
Résumé - Utilisation d'un biogazole comme additif pour la récupération d'huile lourde et de bitume par injection de vapeur à hautes pression et température - L'utilisation d'additifs pour améliorer l'efficacité des procédés de récupération thermique d'huile lourde et de bitume a été étudiée de manière approfondie pendant des décennies. Deux types courants d'additifs utilisés dans des applications thermiques, principalement en récupération assistée par injection de vapeur, consistent en des solvants et des agents tensioactifs. L'utilisation de solvants présente des inconvénients du fait de leur coût élevé et de la difficulté à les récupérer. Le coût et la stabilité des agents tensioactifs aux température et pression de réservoir limitent leur usage. Nous proposons l'utilisation d'un biogazole tel qu'un ester méthylique d'acides gras en tant qu'additif tensioactif pour réduire la tension interfaciale huile lourde/bitume-eau dans les procédés de récupération assistée par injection de vapeur. Les avantages de l'utilisation d'un biogazole en tant qu'additif tensioactif consistent en ce que le biogazole est chimiquement stable aux pression et température d'exploitation du réservoir, qu'il ne dégrade pas la qualité des hydrocarbures produits ni la composition chimique des eaux de production et que son utilisation est économiquement viable.
\end{abstract}

Nous avons mené une série d'expériences de récupération assistée de bitume par injection de vapeur afin de clarifier le potentiel de récupération additionnelle et la capacité d'amélioration d'efficacité du biogazole. De la vapeur à $1,8 \mathrm{MPa}$ et $205^{\circ} \mathrm{C}$ a été utilisée au cours de ces essais, à un débit de $900 \mathrm{~g} / \mathrm{h}$. Le milieu poreux utilisé consistait en un sable pétrolifère à teneur normale en bitume, provenant de l'exploitation d'une mine à ciel ouvert en Alberta du Nord, au Canada. Le sable bitumineux a été mis dans un récipient puis à l'intérieur d'une cellule haute pression. Les expériences de récupération du bitume ont été réalisées en pulvérisant un ester méthylique d'acide gras de colza sur le sable à raison de $2 \mathrm{~g} / \mathrm{kg}$ de bitume. Ces essais montrent une augmentation de la récupération du bitume de plus de $40 \%$. Au cours d'une autre série d'essais, un ester méthylique d'acides gras d'huile de pin a été injecté avec de la vapeur à raison de $8,3 \mathrm{~g}$ de biogazole / $\mathrm{kg}$ de vapeur. Du fait de la solubilité du biogazole dans le bitume, l'effet du biogazole sur la récupération de bitume n'a pas pu être évalué précisément. Les mesures de pression de vapeur réalisées sur les échantillons de biogazole dérivés d'huile de colza et d'huile de pin suggèrent que les compositions à la saturation du biogazole dans la vapeur à $1,8 \mathrm{MPa}$ et $205^{\circ} \mathrm{C}$ sont supérieures d'au moins un ordre de grandeur aux dosages de biogazole requis. Des essais supplémentaires sont planifiés pour lesquels des dosages de biogazole seront réduits jusqu'à environ 0,5 à $1,0 \mathrm{~g}$ de biogazole/kg de vapeur et la solubilité du biogazole dans le bitume sera suivie de près. 


\begin{abstract}
BioDiesel as Additive in High Pressure and Temperature Steam Recovery of Heavy Oil and Bitumen - Use of additives to improve the efficiency of thermal heavy oil and bitumen recovery processes has been studied extensively over the decades. Two common types of additives used in thermal applications, mainly steam assisted recovery, are solvents and surfactants. Commercial use of solvents has setbacks due to their high costs and retrieval difficulties. Cost and stability of the surfactants under reservoir operating temperature and pressure are the major concerns. We propose the use of bioDiesel such as fatty acids methyl ester as a surfactant additive reducing heavy oil/bitumen-water interfacial tension in steam assisted recovery processes. Advantages of using bioDiesel as a surfactant additive are that bioDiesel is chemically stable under the operating pressure and temperature of the reservoir, it causes no harm on bitumen fuel quality and on release water chemistry and its use is economically feasible.

We conducted a series of steam assisted bitumen recovery experiments to clarify the additional recovery potential and efficiency improvement capacity of bioDiesel. High pressure steam at $1.8 \mathrm{MPa}$ pressure, $205^{\circ} \mathrm{C}$ was used in these tests at a $900 \mathrm{~g} / \mathrm{h}$ feed rate. The porous media used was a normal grade oil sands ore obtained from a surface mine operation in Northern Alberta, Canada. Oil sands ore was packed in a basket and placed in a high pressure cell. Bitumen recovery experiments were performed by spraying canola oil fatty acid methyl ester on oil sands ore at a $2 \mathrm{~g} / \mathrm{kg}$-bitumen dosage. These tests show that bitumen recovery efficiency increases over 40\%. In another series of tests, tall oil fatty acids methyl ester was injected into a high pressure steam line at a $8.3 \mathrm{~g}$-bioDiesel/kg-steam dosage. Because of the solubility of bioDiesel in bitumen, the effect of bioDiesel on bitumen recovery could not be accurately concluded. Vapor pressure measurements performed on canola oil and tall oil derived bioDiesel samples suggest that saturation compositions of bioDiesel in steam at $1.8 \mathrm{MPa}$ pressure and $205^{\circ} \mathrm{C}$ are at least one order of magnitude higher than the requested bioDiesel dosages. Further tests are planned by reducing bioDiesel dosages to about 0.5 to $1.0 \mathrm{~g}$-bioDiesel/kilogram-steam and by monitoring the solubility of bioDiesel in bitumen.
\end{abstract}

\section{INTRODUCTION}

In Northern Alberta, four commercial plants are processing surface mineable oil sands deposits for extracting bitumen using an oil sands ore-water slurry based extraction process. This process was first introduced in the 1930s and is known as the Clark How Water Extraction (CHWE) technique (Clark, 1939; Clark and Pasternack, 1932). The current bitumen production through this technique exceeds one-million barrels/day in the region. It has been a well established fact that reduction of the surface and interfacial tensions plays an important role on the efficiency of bitumen recovery in ore-water slurry systems (Bowman, 1968; Baptista and Bowman, 1969; Moschopedis et al., 1977, 1980; Speight and Moschopedis, 1977). In the CHWE process solubility of naturally occurred asphaltic acids in bitumen which are partly aromatic, containing oxygen functional groups such as phenolic, carboxylic and sulphonic types, are increased by the use of caustic $(\mathrm{NaOH})$. Use of $\mathrm{NaOH}$ as an extraction process aid activates the surfactant species in bitumen which reduces the surface and interfacial tensions; however, it harms the release water chemistry and produces tailings with poor settling and consolidation properties (Allen, 2008a, b; Franklin et al., 2002). We have considered the use of other surface active agents to improve the extraction efficiency without harming the fuel quality of the bitumen, but also to mitigate the environmental effects due to changes in water chemistry and geotechnical properties of the tailings.
Use of additives to improve the efficiency of thermal heavy oil and bitumen recovery processes, such as Steam Assisted Gravity Drainage (SAGD) and Cyclic Steam Stimulation (CSS) processes, has been studied extensively over the decades (Al-Bahlani and Babadagli, 2009). Two common types of additives used in thermal applications, mainly steam assisted recovery, are solvents and surfactants, technical and economical feasibility of which are the major factors for their commercial applicability.

Use of BioDiesel (BD) as a surfactant additive to promote bitumen extraction efficiency in oil sands ore-water slurry systems was initiated at our laboratory. BD is fatty acids methyl ester, which is produced from fats (fatty acids glycerides) or fatty acids by simple chemical processes. Our research was focused on the use of surfactants from external sources to eliminate the harmful effects of the additives used in the existing oil sands plants using ore-water slurry based extraction systems (Babadagli et al., 2008). In this effort, we realized that lipid by-products and lipid derivatives such as $\mathrm{BD}$ which is methyl esters of fatty acids $\left(\mathrm{C}_{n} \mathrm{H}_{m}-\mathrm{COOCH}_{3}\right.$; $m<2 n+1)$ and Fatty Acids Mono Glycerides (FAMG, $\left.\mathrm{C}_{n} \mathrm{H}_{m}-\mathrm{COOCH}_{2}-\mathrm{CHOH}-\mathrm{CH}_{2} \mathrm{OH} ; m<2 n+1\right)$ are surfactants effecting the recovery of bitumen in ore-water slurry based extraction systems. We expanded our work to investigate the use of BD, including BD produced from canola oil and Tall Oil Fatty Acids (TOFA) as surfactant additives to improve the efficiency of thermal in situ bitumen recovery processes 
(Babadagli et al., 2009). Tall oil is a by-product of pulp mills using the bleached Kraft process.

Performance of canola oil derived BD as a surfactant additive was demonstrated firstly in an oil sands ore-water slurry based bitumen extraction system. Experiments were performed at $40^{\circ} \mathrm{C}$ using a normal to low grade ore composed of $8.8 \%$ bitumen, $85.0 \%$ solids ( $27.3 \%$ of which $<45$ micron) and $5.5 \%$ moisture. Performance of canola oil derived BD as surfactant additive on bitumen extraction and release water chemistry are presented in Tables 1 and 2, which encouraged us to test the performance of $\mathrm{BD}$ as a surfactant additive in steam assisted bitumen and heavy oil recovery processes also.

\section{EXPERIMENTAL}

The purpose of our research was to demonstrate the effect of $\mathrm{BD}$, specifically fatty acids methyl ester, as a surfactant additive on the efficiency of steam assisted bitumen recovery processes. In all steam assisted bitumen recovery tests, surface mined normal or high grade oil sands ore were used. The ore sample, mostly in the amount of 500 to $900 \mathrm{~g}$, was firmly packed in a stainless steel basket with permeable boundaries (Fig. 1) and placed in the low or high pressure steam chamber. The liquid suspension recovered from the test unit was collected in glass jars. The substances of the jars

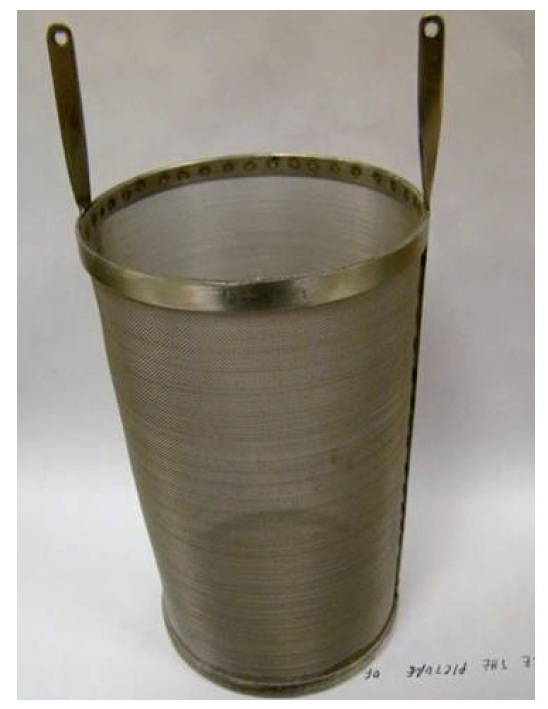

Figure 1

Stainless steel basket holding the oil sands ore samples.

(accumulated in 30 minute periods) were analyzed by the Dean-Stark extraction method to determine its bitumen, solids and water contents. The Dean-Stark method extracts bitumen and $\mathrm{BD}$ together into toluene; therefore, $\mathrm{BD}$ fraction

TABLE 1

Effect of BD as surfactant in ore-water slurry extraction system

\begin{tabular}{|c|c|c|c|c|c|c|c|}
\hline \multirow[b]{2}{*}{ Ore } & \multirow[b]{3}{*}{ Treatment } & \multirow{3}{*}{$\begin{array}{c}\text { Temperature } \\
\left({ }^{\circ} \mathrm{C}\right)\end{array}$} & \multirow{3}{*}{$\begin{array}{c}\text { Additive } \\
\text { (mg/kg-ore) }\end{array}$} & \multicolumn{3}{|c|}{ Froth composition } & \multirow{3}{*}{$\begin{array}{c}\text { Bitumen } \\
\text { Recovery } \\
(\%)\end{array}$} \\
\hline & & & & \multirow{2}{*}{$\begin{array}{l}\text { Bitumen } \\
(\mathrm{g})\end{array}$} & \multirow{2}{*}{$\begin{array}{l}\text { Water } \\
(\mathrm{g})\end{array}$} & \multirow{2}{*}{$\begin{array}{l}\text { Solids } \\
(\mathrm{g})\end{array}$} & \\
\hline ID & & & & & & & \\
\hline ARC1107-3 & Blank & 40 & 0 & 20.3 & 53.8 & 25.9 & 72.5 \\
\hline ARC1107-4 & Blank & 40 & 0 & 19.9 & 54.7 & 25.4 & 74.6 \\
\hline ARC1107-7 & $\mathrm{BD}$ & 40 & 433 & 20.7 & 52.6 & 26.7 & 81.2 \\
\hline ARC1107-8 & $\mathrm{BD}$ & 40 & 433 & 19.8 & 51.7 & 28.5 & 81.4 \\
\hline ARC1107-5 & $\mathrm{BD}$ & 40 & 867 & 22.2 & 52.0 & 25.8 & 82.5 \\
\hline ARC1107-6 & $\mathrm{BD}$ & 40 & 867 & 21.2 & 53.1 & 25.6 & 80.8 \\
\hline ARC1107-21 & Blank & 40 & 0 & 18.7 & 56.4 & 24.9 & 68.0 \\
\hline ARC1107-22 & Blank & 40 & 0 & 18.6 & 55.7 & 25.7 & 69.4 \\
\hline ARC1107-23 & $\mathrm{BD}$ & 36 & 1000 & 18.7 & 55.4 & 25.9 & 71.2 \\
\hline ARC1107-24 & $\mathrm{BD}$ & 36 & 1000 & 20.0 & 55.5 & 24.6 & 72.3 \\
\hline ARC1107-1 & $\mathrm{BD}$ & 40 & 1667 & 20.6 & 51.3 & 28.2 & 78.7 \\
\hline ARC1107-2 & $\mathrm{BD}$ & 40 & 1667 & 20.9 & 50.4 & 28.8 & 82.3 \\
\hline ARC1107-11 & $\mathrm{CaO}+\mathrm{BD}$ & 40 & 400 & 18.9 & 53.1 & 28.0 & 75.7 \\
\hline ARC1107-12 & $\mathrm{CaO}+\mathrm{BD}$ & 40 & 400 & 18.1 & 52.4 & 29.5 & 76.8 \\
\hline ARC1107-9 & $\mathrm{BD}$ & 40 & 3333 & 22.9 & 50.6 & 26.5 & 80.3 \\
\hline ARC1107-10 & $\mathrm{BD}$ & 40 & 3333 & 21.5 & 51.4 & 27.1 & 79.0 \\
\hline
\end{tabular}


TABLE 2

Effect of BD as surfactant additive on release water chemistry

\begin{tabular}{|c|c|c|c|c|c|c|c|c|c|c|c|c|c|}
\hline \multirow{2}{*}{$\frac{\text { Ore }}{\text { ID }}$} & \multirow[b]{2}{*}{ Additive } & \multirow{2}{*}{$\begin{array}{c}\text { Additive } \\
\text { (mg/kg-ore) }\end{array}$} & \multirow[b]{2}{*}{$\mathrm{pH}$} & \multirow{2}{*}{$\begin{array}{c}\text { Conduc. } \\
\text { (mS) }\end{array}$} & \multicolumn{3}{|c|}{ Alkalinity $\left(\mathrm{mg} \mathrm{CaCO}_{3} / \mathrm{L}\right)$} & \multicolumn{4}{|c|}{ Cations (mg/L) } & \multicolumn{2}{|c|}{ Anions $(\mathrm{mg} / \mathrm{L})$} \\
\hline & & & & & Total & $\mathrm{CO}_{3}$ & $\mathrm{HCO}_{3}$ & $\mathrm{Na}$ & $\mathrm{K}$ & $\mathrm{Mg}$ & $\mathrm{Ca}$ & $\mathrm{Cl}$ & $\mathrm{SO}_{4}$ \\
\hline APW & & & 8.7 & 1.265 & 368 & 24 & 344 & 258 & 21 & 10 & 6 & 196 & 8 \\
\hline ARC1107-3 & Blank & 0 & 8.6 & 1.342 & 278 & 10 & 268 & 369 & 22 & 11 & 17 & 170 & 120 \\
\hline ARC1107-4 & Blank & 0 & 8.6 & 1.373 & 283 & 10 & 273 & 356 & 23 & 11 & 17 & 180 & 125 \\
\hline ARC1107-7 & $\mathrm{BD}$ & 433 & 8.5 & 1.397 & 295 & 8 & 298 & 363 & 24 & 11 & 19 & 182 & 123 \\
\hline ARC1107-8 & $\mathrm{BD}$ & 433 & 8.6 & 1.405 & 290 & 8 & 282 & 336 & 26 & 11 & 20 & 189 & 128 \\
\hline ARC1107-5 & $\mathrm{BD}$ & 867 & 8.5 & 1.374 & 291 & 8 & 283 & 353 & 23 & 11 & 19 & 176 & 123 \\
\hline ARC1107-6 & $\mathrm{BD}$ & 867 & 8.5 & 1.417 & 298 & 8 & 290 & 367 & 25 & 12 & 17 & 183 & 126 \\
\hline ARC1107-21 & Blank & 0 & 8.3 & 1.371 & 280 & 2 & 278 & 375 & 21 & 8 & 7 & 193 & 139 \\
\hline ARC1107-22 & Blank & 0 & 8.3 & 1.392 & 286 & 2 & 284 & 385 & 21 & 8 & 9 & 198 & 141 \\
\hline ARC1107-23 & $\mathrm{BD}^{*}$ & 1000 & 8.4 & 1.379 & 291 & 5 & 286 & 324 & 22 & 10 & 15 & 200 & 147 \\
\hline ARC1107-24 & $\mathrm{BD} *$ & 1000 & 8.4 & 1.403 & 291 & 4 & 287 & 331 & 22 & 10 & 16 & 211 & 153 \\
\hline ARC1107-1 & $\mathrm{BD}$ & 1667 & 8.6 & 1.345 & 270 & 10 & 260 & 353 & 22 & 11 & 17 & 171 & 132 \\
\hline ARC1107-2 & $\mathrm{BD}$ & 1667 & 8.6 & 1.385 & 277 & 10 & 267 & 335 & 24 & 11 & 16 & 185 & 132 \\
\hline ARC1107-11 & $\mathrm{CaO}+\mathrm{BD}$ & 400 & 8.3 & 1.365 & 274 & 0 & 274 & 360 & 22 & 9 & 7 & 184 & 142 \\
\hline ARC1107-12 & $\mathrm{CaO}+\mathrm{BD}$ & 400 & 8.4 & 1.369 & 275 & 3 & 272 & 366 & 22 & 8 & 5 & 192 & 134 \\
\hline ARC1107-9 & $\mathrm{BD}$ & 3333 & 8.5 & 1.356 & 291 & 8 & 283 & 338 & 22 & 12 & 20 & 174 & 121 \\
\hline ARC1107-10 & $\mathrm{BD}$ & 3333 & 8.5 & 1.401 & 298 & 8 & 290 & 354 & 23 & 11 & 18 & 183 & 126 \\
\hline
\end{tabular}

APW: Artificial Process Water; $\mathrm{BD}^{*}: 36^{\circ} \mathrm{C}$ temperature

in bitumen could not be detected independently. It is expected that a fraction of BD would be dissolved in bitumen especially under the reservoir operating temperature and pressure. Different analytical methods are being investigated to measure BD solubility in bitumen.

In the Dean-Stark method the cumulative product sample (bitumen, BD, water, and solids) was transferred into a cellulose thimble and extracted with toluene. The extract was cooled, diluted with toluene to $250 \mathrm{~mL}$ in a volumetric flask and $5 \mathrm{~mL}$ samples of which were spread over a filter paper and dried for about 24 hours drying in fume-hood. The toluene extract is composed of toluene, bitumen and BD; therefore, the weight difference by the overnight drying of the filter paper would give the total of bitumen and BD. Weights of filter papers were also measured after several days even weeks of drying. BD evaporated during long drying periods under the room temperature and weight differences of the filter papers provided semi-qualitative information on the BD content and bitumen recovery. Methods are being investigated for the determination of $\mathrm{BD}$ and bitumen contents of the toluene extracts produced by the Dean-Stark extraction method.

\section{RESULTS AND DISCUSSIONS}

Surface and interfacial tensions play an important role in liberation and recovery of bitumen in oil sands ore-water slurry based extraction systems, which should also play the same role in steam assisted bitumen recovery processes. Based on the force balance on a bitumen-solid-water system, with an initial bitumen-solid contact angle $\theta<\pi / 2$, reduction in water-solid $\left(\gamma_{W-S}\right)$ and bitumen-water $\left(\gamma_{B-W}\right)$ interfacial tensions promotes the disengagement of bitumen from the solid since the inequality:

$$
\gamma_{B / S}+\gamma_{B / W} \cos \theta \leq \gamma_{W / S}
$$


which favors wetting of solid with water rather than with bitumen and wetting of bitumen with water rather than with solid (Babadagli et al., 2009).

Surfactant behavior the BD has been tested by observing the contact angles of a BD droplet on bitumen surface, a process water droplet on bitumen surface and a drop of $\mathrm{BD}$ in process water; photographic images of which are presented in Figure 2. These photographs show that BD wets both bitumen and water, as expected because of its hydrophilic $\left(\mathrm{COOCH}_{3}\right)$ and hydrophobic $\left(\mathrm{C}_{n} \mathrm{H}_{m}\right)$ functional groups; therefore, $\mathrm{BD}$ acts as surfactant promoting wetting of bitumen with water. The measured interfacial tensions of water-air $\left(\gamma_{W}\right)$, BD-air $\left(\gamma_{B D}\right)$ and BD-water $\left(\gamma_{B D / W}\right)$ at $25^{\circ} \mathrm{C}$ were 59.2, 28.6 and $9.7 \mathrm{dyns} / \mathrm{cm}$ respectively also supports the surfactant behavior of BD.

Visual inspection of the condensates obtained from steam only and steam and BD bitumen recovery tests depicted in Figure 3 shows that bitumen contained in condensate from the steam-only tests had a much higher tendency to stick on the jar's interior surface. This observation also suggests that BD-water emulsion promotes the mobilization of bitumen from solid surfaces to liquid suspension, which could also mobilize bitumen from the sands surface to condensed steam in the reservoir. Formation of BD in water emulsion, as seen in Figure 3, also shows that BD could be delivered into the reservoir by injecting a liquid BD into the high pressure steam.

\subsection{Low Pressure Steam Assisted Bitumen Recovery Tests}

The first set of steam assisted bitumen recovery tests were performed on a normal grade oil sands ore $(8.5 \%$ bitumen, $86.2 \%$ sand, $4.9 \%$ moisture; $17.5 \%$ of the solids less than 45 micron size) using atmospheric pressure steam and injecting

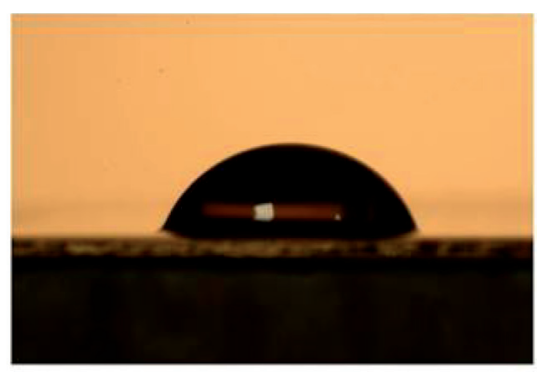

Water on bitumen

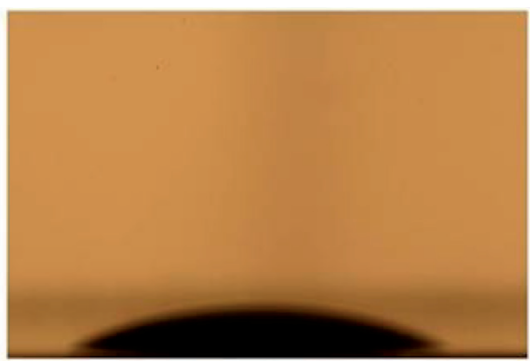

BD on bitumen

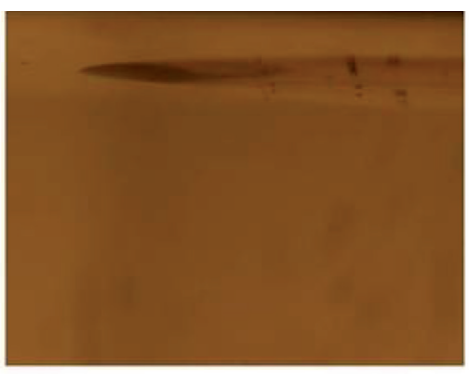

$\mathrm{BD}$ in water

Figure 2

Water and $\mathrm{BD}$ on bitumen $\left(\gamma_{B D / B}<\gamma_{B D / B}\right)$ and spreading of BD in water.

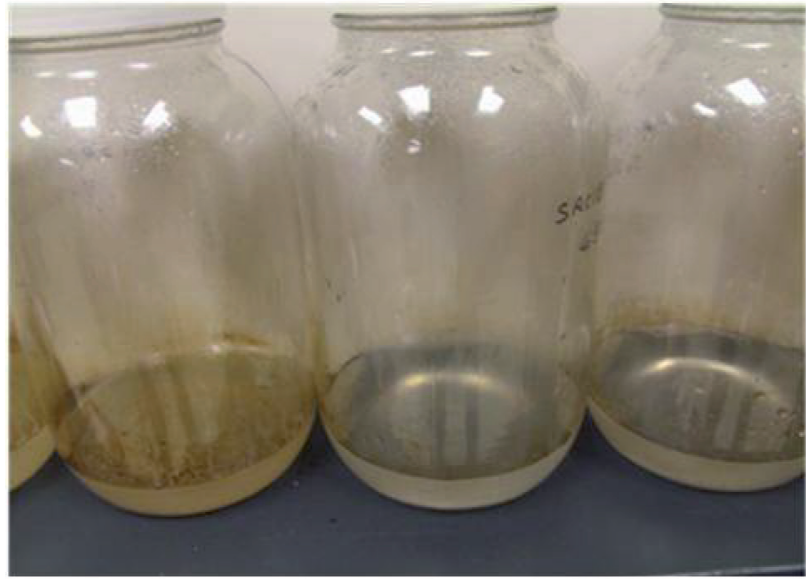

a)

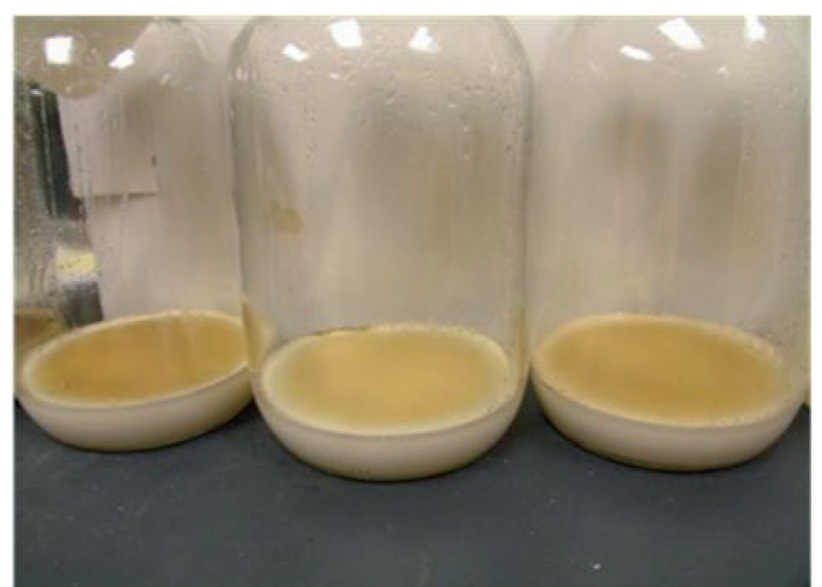

b)

Figure 3

Condensates recovered with: a) steam only and b) steam and BD. 


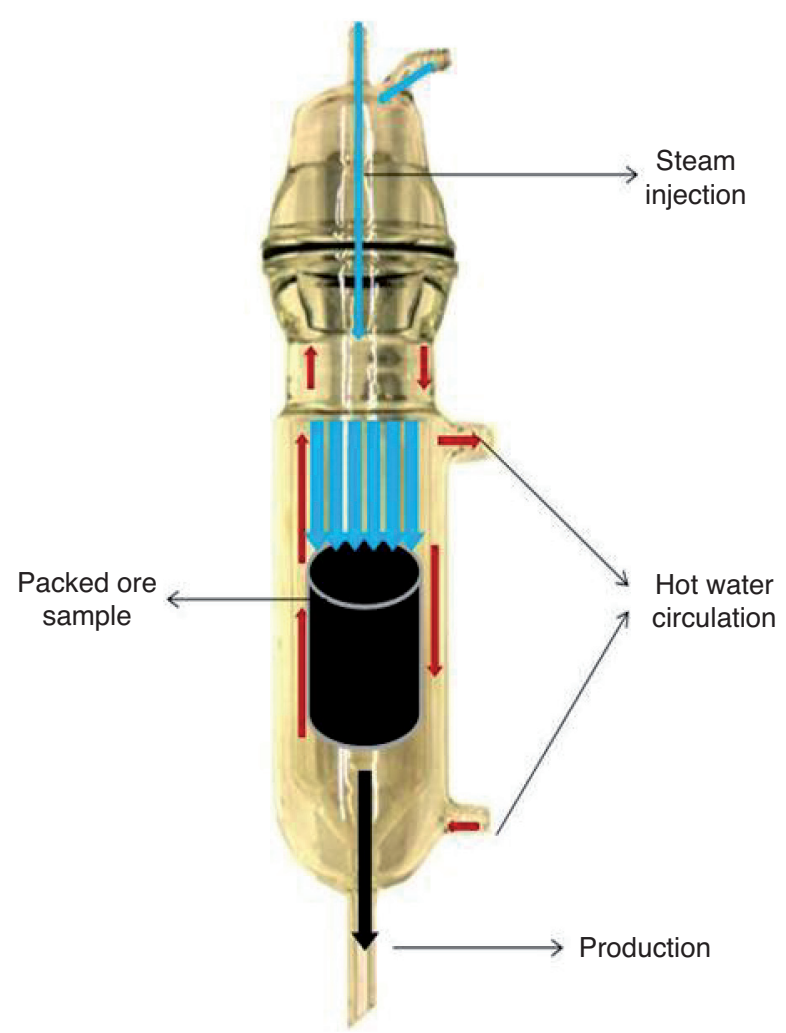

Figure 4

Low pressure steam assisted bitumen recovery test apparatus.

a canola oil derived $\mathrm{BD}$ at $1 \mathrm{~g} / \mathrm{kg}$-bitumen dosage into the low pressure steam line, as depicted in Figure 4. The cumulative bitumen-water emulsion products were collected every 30 minutes intervals and their bitumen contents were determined using the Dean-Stark extraction. Cumulative bitumen recoveries as a function of time with steam only and with steam and BD are presented in Figure 5. Test results showed that BD addition in small dosages increases bitumen recovery efficiency in the early phase of the test.

\subsection{High Pressure Steam Assisted Recovery Tests by Spraying BD on Oil Sands Ore}

Steam assisted bitumen recovery tests were also performed on the same ore using a high pressure steam at 1.8 $\mathrm{MPa}$ pressure and $205^{\circ} \mathrm{C}$ temperature. In these tests the rate of steam injection was $900 \mathrm{~g} / \mathrm{h}$ and a canola oil derived BD was sprayed on an oil sands sample at $2 \mathrm{~g} / \mathrm{kg}$-bitumen dosage before it was compacted into the sample basket. The purpose of this experiment was to obtain insight into the effects of the BD on the process if it is introduced into the system successfully and

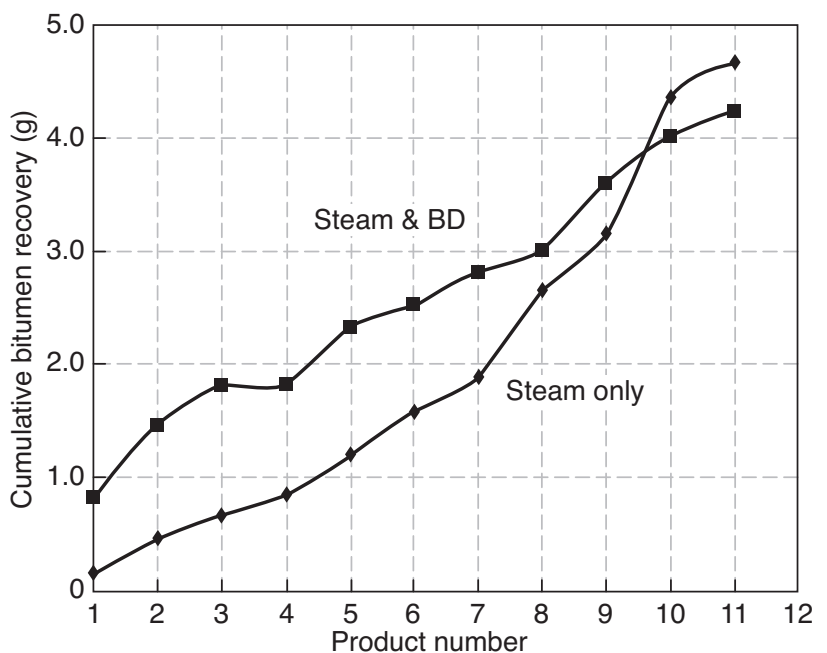

Figure 5

Low pressure steam tests, BD injected into steam line (Babadagli et al., 2009).

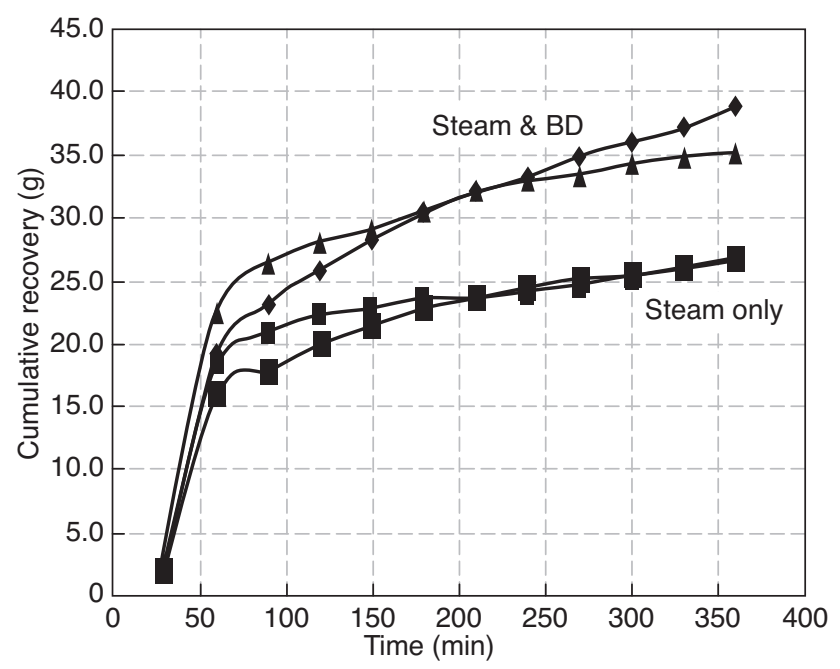

Figure 6

High pressure steam tests by spraying BD onto oil sands ore.

spread in the system homogeneously. Steam pressure and temperature were selected to stimulate a typical steam assisted bitumen recovery reservoir operating conditions in Alberta. The cumulative bitumen-water emulsion products were collected every 30 minutes intervals and their bitumen contents were determined using the Dean-Stark extraction. Cumulative bitumen recoveries as a function of time with steam only and with steam and BD are presented in Figure 6. Remarkable improvement in bitumen recovery was observed with $\mathrm{BD}$ addition at a dosage of $2 \mathrm{~g}-\mathrm{BD} / \mathrm{kg}$-bitumen. 


\subsection{High Pressure Steam Assisted Recovery Tests by Injecting BD into Steam}

A separate set of high pressure steam assisted bitumen recovery experiments were performed by continuous injection of liquid BD into the high pressure steam line instead of preprocessing the ore with $\mathrm{BD}$. In these tests steam was injected at $10 \mathrm{~g} / \mathrm{min}(600 \mathrm{~g} / \mathrm{h})$ to $20 \mathrm{~g} / \mathrm{min}(1200 \mathrm{~g} / \mathrm{h})$ and BD injection dosage was set at $7.5 \mathrm{~g} / \mathrm{h}$ (about $8.3 \mathrm{~g}-\mathrm{BD} / \mathrm{kg}$ steam) to $0.65 \mathrm{~g} / \mathrm{h}(0.9 \mathrm{~g}-\mathrm{BD} / \mathrm{kg}$-steam). In these tests a high grade ore composed of $12.0 \%$ bitumen, $84.7 \%$ solids $(6.4 \%$ of which less than 45 micron) and $2.8 \%$ moisture and a tall oil derived $\mathrm{BD}$, i.e. tall oil fatty acids methyl ester, was used. The cumulative bitumen-water emulsion products were collected every 30 minutes intervals and their bitumen contents were determined using the Dean-Stark extraction method. Cumulative toluene extractable recoveries (bitumen and BD combined) as a function of time with steam only and with steam and BD are presented in Figure 7. Data presented in Figure 7 were produced after overnight drying of the DeanStark extract samples sprayed on the filter papers. Data presented in Figure 7 would be more informative if the BD content of the Dean-Stark extract is known.

Cumulative toluene extracts for one of the Run 4 (i.e. the Dean-Stark extract samples sprayed on the filter papers) were recorded after long time drying periods; results of which are presented in Figure 8. The first line from the top in Figure 8 is the cumulative recovery curve for Run 4 generated by overnight drying of the Dean-Stark extract samples sprayed on the filter papers. Comparison of the data presented in Figure 7 and Figure 8 show that about $6.30 \mathrm{~g}$ BD was in the Dean-Stark extracts cumulatively at the first place (i.e. total recoveries recorded for Run 4 on March 12, March 18 and

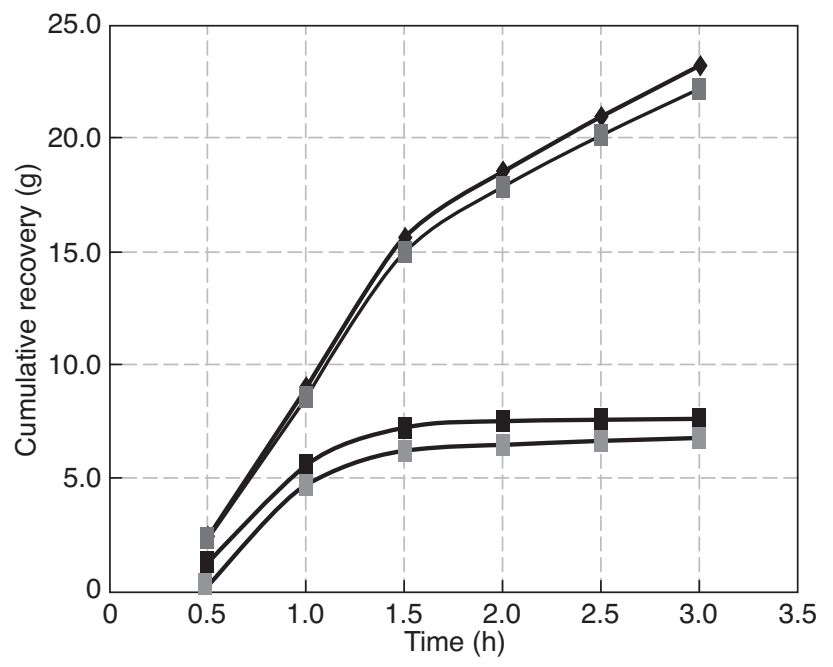

Figure 7

High pressure steam tests by injecting BD into steam line.

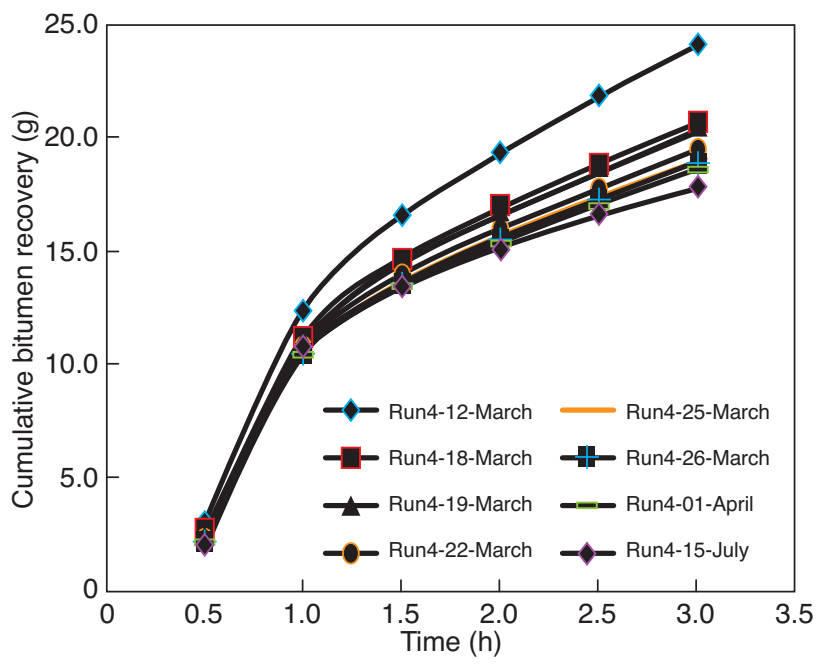

Figure 8

Cumulative bitumen recovery affected by the presence of $\mathrm{BD}$ in Dean-Stark extracts.

July 15 were $24.15 \mathrm{~g}, 20.67 \mathrm{~g}$ and $17.85 \mathrm{~g}$ respectively). The trend in recovery measurements as depicted in Figure 8 suggests that $\mathrm{BD}$ is an effective surfactant additive in steam assisted bitumen recovery process.

The presence of BD in the Dean-Stark extracts is caused by the solubility of BD in bitumen as well as the formation of the BD-water emulsion. Additional work is planned to quantify the amount of BD dissolved in bitumen under high pressure-high temperature reservoir operating conditions. New steam assisted bitumen recovery tests are also under consideration by reducing the BD feed rate by 10 folds while keeping the other parameters unchanged, the results of which would allow us to evaluate the surfactant effect of BD additive in steam assisted bitumen recovery processes.

The use of BD as a surfactant additive in steam assisted bitumen recovery processes, therefore, would depend on three major factors:

- surfactant characteristics of BD reducing bitumen-water interfacial tension $\gamma_{B / W}$;

- chemical stability and concentration of BD in saturated steam, which requires BD to possess sufficient vapor pressure so that saturation composition of $\mathrm{BD}$ in steam exceeds its required dosage; and,

- availability of BD at the places in the reservoir where it is needed the most; i.e., where the steam condenses, which is the zone adjacent to the zone saturated by steam as depicted in Figure 9.

Simulated distillation curves for BD derived from canola oil, COFAME (Canola Oil Fatty Acids Methyl Ester) and BD derived from tall oil, TOFAME (Tall Oil Fatty Acids Methyl Ester) are presented in Figures 10 and 11. Simulation 


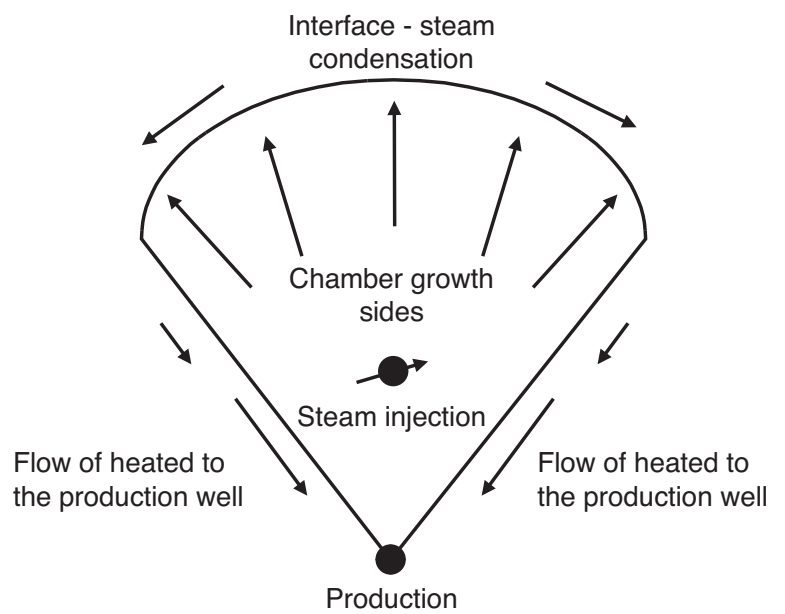

Figure 9

Visualization of the SAGD operation.

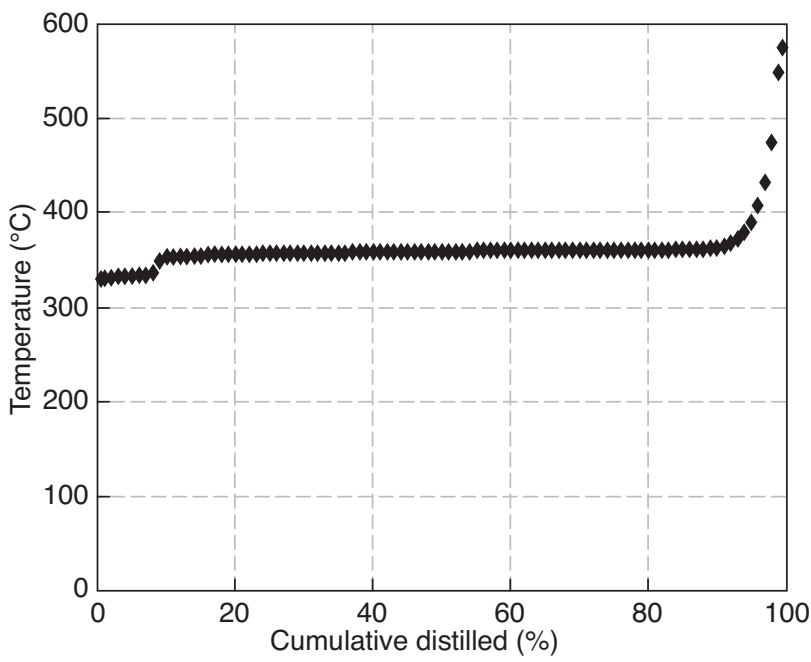

Figure 10

Simulated distillation curve of COFAME.

distillation curves suggest that both $\mathrm{BD}$ are of acceptable purity for their use as surfactant additive in thermal recovery processes. Vapor pressure of canola oil and tall oil fatty acids methyl esters were also measured at different temperatures. Vapor pressure data indicate that the expected vapor pressures of COFAME and TOFAME at $200^{\circ} \mathrm{C}$ would be about $0.69 \mathrm{kPa}$ and $1.67 \mathrm{kPa}$, which are comparable with the vapor pressures of similar fatty acids methyl esters (Yuan et al., 2005). These predicted vapor pressures at $200^{\circ} \mathrm{C}$ suggest that if steam saturated with $\mathrm{BD}$ is assumed to be an ideal mixture, the saturation concentration of BD in steam would be at least one order of magnitude greater than the required $\mathrm{BD}$ dosage in steam. As an example, if $\mathrm{BD}$ is used as a surfactant additive in steam assisted bitumen recovery, for a

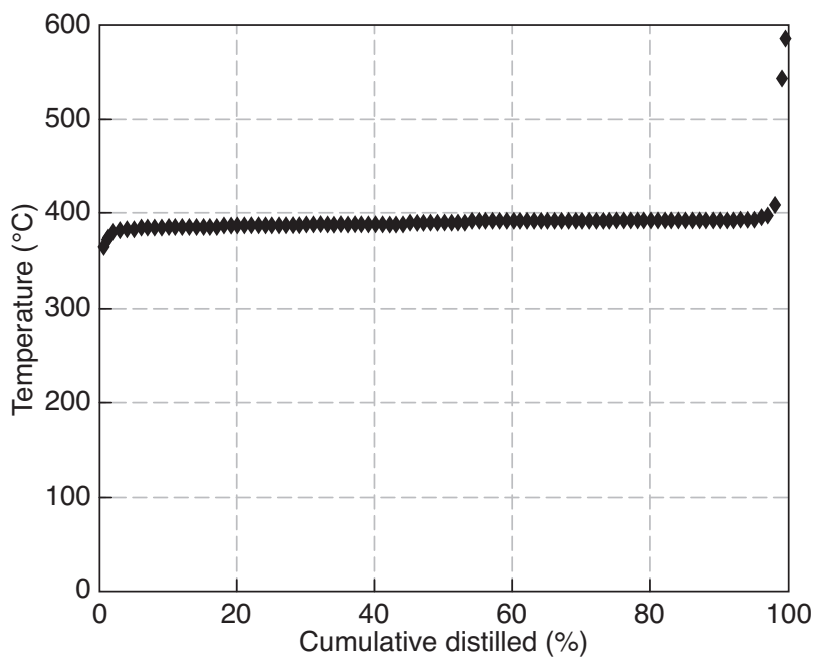

Figure 11

Simulated distillation curve of TOFAME.

Water-to-Oil (W/O) ratio of 3 and a dosage of $2 \mathrm{~g}-\mathrm{BD} / \mathrm{kg}$ bitumen, the required $\mathrm{BD}$ dosage in steam is estimated as $0.07 \%$ by mass $(0.320 \mathrm{~kg}-\mathrm{BD} / 480 \mathrm{~kg}$-steam $)$, while the saturation compositions for canola oil and tall oil fatty acids methyl esters in steam are estimated as $0.65 \%$ and $1.67 \%$ by mass, respectively. Visual comparison of the condensates obtained from injecting steam only and steam and BD, as depicted in Figures 3a, b, supports the predictions made using the vapor pressure data: BD vaporized in the high pressure steam line and condensed with steam in the high pressure cell.

Differences in the vapor pressures of canola oil and tall oil fatty acids methyl esters suggest that the physical properties and performance of other fatty acids methyl or other esters, should also be studied. Vapor pressure, surfactant behavior and chemical stability of the BD should match the desired properties under the operating temperature and pressure of the reservoir.

Solubility of BD in bitumen could also be a concern. The $\mathrm{BD}$ introduced into the reservoir with steam may dissolve in the remaining bitumen present in the saturation zone and may not reach to the places where it would be needed to promote bitumen recovery efficiency. Dissolution of BD in bitumen could be controlled by the diffusivity coefficient, which would be in the order of $10^{-6} \mathrm{~cm}^{2} / \mathrm{s}$ and the steam-bitumen interfacial surface area in the saturation zone, the combined effect of which could be significant. For an effective use of $\mathrm{BD}$, it should be used as a surfactant additive from the early phase of the steam assisted bitumen recovery process. If BD is planned to be used as a surfactant additive for secondary recovery, it should be used in reservoirs with shrunken saturation zones, i.e., in cooled reservoirs. 
$\mathrm{BD}$ derived from different fatty acids feedstock would have different vapor pressure and surfactant characteristics. BD is produced by simple chemical processes and sold at about $\$ 1.80 / \mathrm{L}$, which would cost $\$ 0.58-\mathrm{BD} / \mathrm{bbl}$-bitumen corresponding to consumption dosage of $200 \mathrm{mg}-\mathrm{BD} / \mathrm{bbl}$-bitumen.

\section{CONCLUSIONS}

Laboratory scale steam assisted bitumen recovery test results suggest that $\mathrm{BD}$ could be used as a surfactant additive to promote bitumen recovery efficiency. Solubility of BD in bitumen may, however, limit the performance of $\mathrm{BD}$ as a surfactant additive. Therefore, the application conditions should be determined by considering the phase behavior of $\mathrm{BD}$ at given steam injection conditions. The BD injected may be dissolved in bitumen through mass transfer instead of acting as a surfactant if the $\mathrm{BD}$ is introduced into the system as purely vapor and the reservoir temperature is the same as the steam temperature. Steam is expected to be the carrier of the $\mathrm{BD}$ (in the vapor form) but the condensation of $\mathrm{BD}$ is needed to act as interfacial tension reduction agent. It is also critical to determine the right time to start the $\mathrm{BD}$ injection. Based on the observations through the experimental study we conducted so far, $\mathrm{BD}$ is recommended to be injected at the beginning of the thermal process when the reservoir is cool. Application of $\mathrm{BD}$ in an already heated area requires further research to determine the $\mathrm{BD}$ injection conditions.

Obviously, this paper contains initial experimental results obtained from re-packed sand pack models. For real world applications, the next step is to follow the guidelines provided in this work and perform experiments on original (and preserved) core samples. This will lead to a numerical model study after obtaining the data needed, such as alteration in viscosity of oil and interfacial properties, from experimental study. All these effort will enlighten the way forward to a field pilot test.

\section{ACKNOWLEDGMENTS}

This paper is the revised and improved version of SPE 133376 presented at the SPE Western Regional Meeting held in Anaheim, California, USA, 27-29 May 2010. The authors acknowledge the financial support provided by the Industrial Research Assistance Program-National Research Council (IRAP-NRC), Alberta Advanced Education and Technology and Alberta Energy Research Institute (AERI). Technical assistance provided by G. Kovacik and C. Pack of Alberta Innovates Technology Futures and Dr. H. Yarranton of the University of Calgary are appreciated. Sample preparation and laboratory analyses performed by V. Er, B. Feland and A. Gieleciak are greatly treasured.

\section{REFERENCES}

Allan E.W. (2008a) Process Water Treatment in Canada's Oil Sands Industry: I. Target Pollutants and Treatment Objectives, J. Environ. Eng. Sci. 7, 2, 123-138.

Allan E.W. (2008b) Process Water Treatment in Canada's Oil Sands Industry: II. A Review of Emerging Technologies, J. Environ. Eng. Sci. 7, 5, 499-524.

Al-Bahlani A.M., Babadagli T. (2009) SAGD Laboratory and Numerical Simulation Studies: A Review of Current Status and Future Issues, J. Petrol. Sci. Eng. 68, 135-150.

Babadagli T., Er V., Naderi K., Burkus Z., Ozum B. (2009) Use of BioDiesel as an Additive in Thermal Recovery of Heavy Oil and Bitumen, Canadian International Petroleum Conference, Calgary, Alberta, Canada, June 16-18.

Babadagli T., Burkus Z., Moschopedis S.E., Ozum B. (2008) Bitumen Extraction from Oil Sands Ore-Water Slurry Using CaO (Lime) and/or Ozone, SPE 117677, SPE/PS/CHOA International Thermal Operations and Heavy Oil Symposium, Calgary, Alberta, Canada, October 20-23.

Baptista M.V., Bowman C.W. (1969) The Flotation Mechanism of Solids from the Athabasca Oil Sands, 19th Can. Chem. Eng. Conf., Edmonton, Alberta, Canada, October.

Bowman C.W. (1968) Molecular and Interfacial Properties of Athabasca Tar Sands, Proceedings of the 7th World Petroleum Congress, Elsevier, Mexico City, Mexico, pp. 583-604.

Clark K.A. (1939) The Hot Water Method for Recovering Bitumen from Bituminous Sand, Report on Sullivan Concentrator, Alberta Research Council, Alberta, Canada.

Clark K.A., Pasternack D.S. (1932) Hot Water Separation of Bituminous Sand, Ind. Eng. Chem. 24, 1410.

Franklin J.A., Renault S., Croser C., Zwiazek J.J., MacKinnon M. (2002) Jack Pine Growth and Elemental Composition are Affected by Saline Tailings Water, J. Environ. Qual.31, 648-653.

Moschopedis S.E., Schulz K.F., Speight J.G., Morrison D.N. (1980) Surface-Active Materials from Athabasca Oil Sands, Fuel Process. Technol. 3, 55-61.

Moschopedis S.E., Fryer J.F., Speight J.G. (1977) Water-Soluble Constituents of Athabasca Bitumen, Fuel 56, 109-110.

Speight J.G., Moschopedis S.E. (1978) Factors Affecting Bitumen Recovery by the Hot Water Process, Fuel Process. Technol. 1, 4, 261-268.

Yuan W., Hansen A.C., Zhang Q. (2005) Vapor Pressure and Normal Boiling Point Predictions for Pure Methyl Esters and BioDiesel Fuels, Fuel 84, 943-950.

Final manuscript received in August 2011 Published online in May 2012 